\title{
«La Trilogia de València» de Joan Francesc Mira: una aproximació geogràfica a la literatura i l'oralitat
}

\author{
Anna Laura Díaz Iglesias (andiaz@uji.es) \\ Universitat Jaume I
}

\section{Espai, literatura i oralitat}

L'home i l'espai urbà han esdevingut un tot des de l'entrada de la modernitat. Aquesta «nova» situació social es realitza de manera progressiva depenent del lloc. Per tant, no és homogènia. La realitat, però, és que les ciutats són un element indestriable de l'individu actual, i això es reflecteix no només en la seua experiència de la quotidianitat sinó també en les seues creacions artístiques. Aquest home modern té la pretensió de donar compte dels nivells i dels processos que experimenta el jo (no solament l'individual, també de la collectivitat).

Una bona mostra de la relació mantinguda entre l'home i les urbs la dóna el fet que la literatura i les ciutats han estat una qüestió recurrent al llarg de la Història. ${ }^{1}$ L'aspecte constant ha sigut la contribució d'aquest conjunt en la vivificació dels espais i alhora, en moltes ocasions, la capacitat de construir una al·legoria identitària. En la narrativa de Joan Francesc Mira, el procés de lectura posarà en relació la ciutat (o territori) ${ }^{2}$ i el lector, el qual haurà de descodificar la informació continguda en cada petit enigma que l'autor plantege de manera virtual en aquestes píndoles locatives.

Resultarà veritablement interessant, des d'un posicionament didàctic i des de l'educació literària, treballar i transmetre l'alumnat ${ }^{3}$ de secundària, ${ }^{4}$ que comença a desenvolupar amb una major maduresa i criteri la seua competència literària, l'aspecte enigmàtic que confereixen els espais urbans de les novel-les, alhora que abordarem diferents continguts de l'assignatura de Llengua i Literatura Valencianes.

En aquest sentit, les possibilitats que ofereixen les obres de Joan Francesc Mira, i més concretament les de la «Trilogia de València», ${ }^{5}$ permetran el professorat presentar i acostar la narrativa d'una manera més dinàmica: amb una ruta literària. La multiplicitat creativa que ofereix la narrativa desplega tot un ventall de possibilitats locatives; en el cas de l'autor que hem escollit les coordenades on situa l'acció estaran clarament delimitades: València (i el País Valencià). Aquest aspecte no és intranscendent, perquè el fet de dotar el text de proximitat i d'elements recognoscibles facilita el pacte literari i la immersió del lector en

${ }^{1}$ Cal considerar que la funció que acomplia aquest binomi era diferent depenent del context històric.

${ }^{2}$ En la producció novel-lística de Joan Francesc Mira, tant la ciutat de València, com el País Valencià tindran una presència important.

${ }^{3}$ Que entenem que és un lector jove per edat i per maduresa en la comprensió lectora.

${ }^{4}$ Segon cicle de l'ESO.

${ }^{5}$ Els treballs perduts (1989), Purgatori (2003) i El professor d'història (2008). 
la novellla. La ciutat esdevindrà un plànol que sobrepassarà el sentit habitual de conjunt de carrers, és a dir, amb una càrrega semiòtica que adoptarà una forma física i que caldrà tractar adequadament.

Si fem una mirada en perspectiva, ens adonem que en el conjunt de la producció narrativa de Mira es traça un recorregut espacial amb voluntat testimonial, és a dir, que pretén ser una mena de crònica que aprofita diferents racons de la ciutat de València com si fóra el recorregut d'una gimcana; d'aquesta manera l'autor acompanya els lectors per una sèrie de llocs que són parada obligada (al seu entendre). Aquestes «estacions» tenen la seua raó de ser en una doble rellevància: d'una banda, la rememoració personal; de l'altra, com a poble, com a conjunt humà amb uns trets característics específics. Així, d'una banda, l'experiència vital de Joan Francesc Mira i el seu entorn pròxim seran recurs de la ficcióo ${ }^{\text {i }}$ objecte de l'educació lingüística i literària d'acord amb la nostra proposta.

A mesura que el lector s'endinsa pels diferents camins que dibuixa la novel-lística de l'autor que ens ocupa, inevitablement es posa en ordre l'experiència pròpia i es configura la seua identitat: el territori com a element constructor d'un discurs personal i, dins d'aquest, el nacional i l'identitari.

En aquest punt s'introdueix el concepte de flâneur, del caminant que vagareja per les ciutats i a través de la seua mirada genera un discurs concret envers el tràfec social que l'envolta. Tot i que aquesta modalitat de mostrar els espais des de dins és una forma recurrent en Joan Francesc Mira. Les novel·les de la «Trilogia de València» potser siguen les que més clarament evidencien el sentit de ruta. D’aquesta manera, la presentació de l'espai urbà ens permetrà implementar una proposta didàctica alternativa (Bataller: 2014) pel que fa al món literari, no tant des d'una perspectiva teòrica, sinó experiencial i que permetrà, a més, un coneixement multidisciplinari i integral. La ruta literària presenta un nou model metodològic que no és aliè als canvis socioculturals i econòmics que afecten tota la nostra societat. És evident, però, que els nous temps també han arribat als centres docents i això ha provocat que al professorat se li presenten nous plantejaments programàtics dins l'aula.

La reinvenció, per tant, de la metodologia de l'ensenyament de la llengua i de la literatura posa de relleu la importància que tenen la immediatesa, l'espai i l'oralitat.

Aquesta darrera qüestió ha provocat que es desencadene «una valoració de l'especificitat dels usos orals com a fet comunicatiu i una concepció de la llengua oral com a part integrant dels usos lingüístics» (Vilà, 2002: 127).

A propòsit de les noves necessitats s'han generat, també, les dificultats, d'altra banda lògiques, entre els equips docents per tal d'inserir el treball de l'oralitat a les aules d'una manera seriosa, sistemàtica i amb una metodologia específica i fonamentada. Per tal de fer una mica de llum a aquest assumpte, no em vull estar de recollir ací les propostes que reprèn Vilà en un dels seus treballs en solitari (2002), ja que acoten d'una manera bastant acurada l'aspecte que ens interessa. Així, la matriu d'aspectes que hem de (re)considerar són els següents: la necessitat d'aclarir la finalitat, els continguts i la metodologia de

\footnotetext{
${ }^{6}$ No estem referint-nos a literatura autobiogràfica, sinó a l'experiència personal com a font d'inspiració en la construcció del discurs literari de Joan Francesc Mira.
} 
l'ensenyament de l'oral en qualsevol nivell d'escolaritat obligatòria i postobligatòria; la superació de l'espontaneïtat i la creença en un desenvolupament «natural» de l'ús de la llengua oral, i la superació de la simple pràctica de la llengua oral a partir de les diverses situacions de comunicació a classe.

L’ensenyament sistemàtic de la producció de discursos orals (l'estudi lingüístic de documents orals autèntics i dels procediments retòrics i discursius implicats) es considera la manera més eficaç de fer progressar els alumnes en el domini dels recursos de les manifestacions orals de la llengua; el qüestionament de la visió que separa totalment la llengua oral de l'escrita, i també d'aquella que presenta el llenguatge oral com una simple transcripció de l'escrit; la coordinació entre l'ensenyament de la llengua l'oral a l'escrita. Aquesta concepció implica interrelacionar les activitats orals i escrites, i estudiar el grau d'interdependència en determinats gèneres discursius; la necessitat de no limitar l'ensenyament als usos informals i col-loquials de la llengua, tot i que els considerem imprescindibles en la situació sociolingüística del nostre país. Els textos orals complexos de caràcter formal mereixen un tractament profund i sistemàtic en els nivells d'ensenyament superior.

Així, davant d'aquests plantejaments, una de les millors opcions que es poden considerar per a dur endavant el treball amb l'alumnat de la llengua oral és la del projecte didàctic que contemple la ruta literària. La raó és ben senzilla:

La llengua oral [...] requereix la coordinació i la integració de diferents tipus d'objectius i de continguts en activitats globals d'ús de la llengua, que els donin sentit i que els facin significatius per als alumnes. Els beneficis que s'atribueixen al treball per projectes per a l'aprenentatge de la llengua [...] tenen relació: amb la motivació que suposa resoldre un problema concret en una situació real d'ús del llenguatge; amb les possibilitats d'interacció amb els companys i amb el professor [...]; amb la diversitat de tasques que implica, i, per últim, amb la necessitat de verbalitzar problemes i solucions (Vilà, 2002: 129).

En aquesta ocasió, ens aproximarem a l'estudi de la llengua oral i de l'educació literària a través de la novel-lística miriana, per totes les possibilitats que posa al nostre abast per tal de desenvolupar el procés d'ensenyança-aprenentatge. Així, s'executaran una sèrie d'activitats de producció lingüisticoliterària per part de l'alumnat que facilitaran la interacció i el contacte amb un text que s'ha de fer propi i que, fins i tot, ens permetrà experimentar-lo locativament. Tal com apunta el mateix Joan Francesc Mira (2011), la literatura és un bé comú, i cal que li traguem el rendiment didàctic que ofereix. I és que:

Dejando aparte mitologías y leyendas, los lectores sentimos una emoción especial, difícilmente expresable, al visitar las casas, las calles y los paisajes que transitaron y donde imaginaron sus obras nuestros autores más admirados. Somos adictos a peregrinaciones devotas para ver los rincones y los cielos que contemplaron aquellos a quienes debemos tantos momentos de emoción y de iluminación. Los comprendemos mejor y nos sentimos más cerca de ellos al conocer el marco, a veces ya muy deteriorado por el tiempo inmisericorde, en que transcurrieron sus vidas y se fraguó su escritura (Savater, 2013: 13). 


\section{Un nou model en la didàctica de la llengua i de la literatura}

Aquest treball es desenvoluparà en diverses fases al llarg del curs. L'activitat de la ruta literària representarà, doncs, l'eclosió o producte final derivat de totes les tècniques, tant teòriques com pràctiques, consolidades durant les sessions prèvies: definició i concreció de la proposta, preparació de les parades escaients en la ruta literària i preparació de la posada en marxa de la ruta. Malgrat tot, cal considerar que:

el treball fora de l'aula no ha de ser entès com una activitat determinada principalment per l'espai físic on es realitza, sinó, més aviat, per l'espai mental en què es genera i la predisposició cognitiva a què dóna lloc. D’aquesta manera, l'espai mental que es deriva del treball fora de l'aula promou l'adquisició de coneixements, atès que suscita la formació de preguntes i explicacions; facilita la creació de valors, atès que permet, al mateix temps, l'adquisició d'una formació reglada i no reglada; exigeix el domini de tècniques i destreses; condueix a l'aprenentatge i al desenvolupament d'actituds crítiques i, de manera paral-lela, al procés d'aprenentatge, reforça llaços d'amistat, solidaritat i treball en grup. A banda, el treball fora de l'aula, també és causa de motivació, perquè amb la sortida es trenca la dinàmica habitual de la classe i s'interromp la rutina de l'aprenentatge quotidià, encara que es continuï amb l'aprenentatge programat (Serrano, 2007).

Per donar pas a la primera fase, cal haver mantingut una presa de contacte amb l'alumnat, per això és pertinent iniciar aquesta activitat a la segona avaluació; de fet, les sessions de la primera part del curs serviran per contactar amb els alumnes i situar-los en el nivell teòric adient, en relació amb l'assignatura. D'aquesta manera, una vegada iniciada la complicitat professorat-alumnat cal presentar-los l'autor i les novel-les que es treballaran durant el curs: Els treballs perduts (1989), Purgatori (2003) i El professor d'història (2008); la tria d'aquests texts no és aleatòria. De fet, està pensada per abordar, a més de l'estudi de la literatura catalana contemporània produïda al País Valencià, aspectes que traspassen el món de la ficció, com ara la identitat:

La literatura forma part del patrimoni collectiu, i això es reforça encara si, tal com passa ben sovint, la paraula escrita, la narració o el poema, naixen o creixen en un territori concret, quan empren la llengua d'aquest territori, o quan reflecteixen, descriuen o fins i tot inventen un espai real o mític (Mira, 2011: 75).

\section{La ruta com a eina (d'innovació) educativa}

Els objectius generals de l'assignatura de Llengua i Literatura Valencianes que s'han treballat en aquesta proposta didàctica són els següents:

a) Comprendre els diferents tipus de textos, orals i escrits, i les seues distintes estructures formals i, especialment, en l'àmbit acadèmic i en els mitjans de comunicació, posar atenció en els elements del context que en condicionen una adequada interpretació. 
b) Expressar-se oralment i per escrit, especialment en l'àmbit acadèmic, per mitjà de discursos adequats, coherents, cohesionats i correctes, sabent utilitzar i valorar la llengua oral i la llengua escrita com a mitjans eficaços per a la comunicació interpersonal, l'adquisició de coneixements nous, la comprensió i l'anàlisi de la realitat i l'organització racional de l'acció.

c) Adquirir uns coneixements gramaticals, sociolingüístics i discursius per a ser utilitzats en la comprensió, l'anàlisi i el comentari de textos i en la planificació, la composició i la correcció de les pròpies produccions.

d) Analitzar críticament els discursos orientadors de l'opinió i els discursos reguladors de la vida social, i valorar la importància de l'acostament a aquests discursos per al coneixement de la realitat.

e) Utilitzar adequadament la llengua com a instrument per a l'adquisició de coneixements nous i per a produir i interpretar textos propis de l'àmbit acadèmic, obtenint, interpretant $\mathrm{i}$ valorant informacions de diferents tipus i procedències, sent capaç d'emprar tècniques de recerca, elaboració i presentació de la informació, utilitzant, amb autonomia i esperit crític, els mitjans tradicionals i les noves tecnologies.

f) Interpretar i valorar críticament les obres literàries a partir del coneixement de les formes convencionals específiques (gèneres, procediments retòrics, etc.), de la informació pertinent sobre el context historicocultural de producció, així com sobre les condicions actuals de recepció, i dels trets identificadors dels grans períodes en valencià i en castellà, així com d'obres i autors significatius, utilitzant de manera crítica les fonts bibliogràfiques i documentals adequades per al seu estudi.

g) Llegir i valorar les obres literàries com a font d'enriquiment personal i de trobar plaer, com a manifestacions de la sensibilitat artística de l'ésser humà i com a expressió de la identitat cultural dels pobles, apreciant el que el text literari té de representació i d'interpretació del món.

La realitat és que hi trobem, a més, alguns aspectes afegits que resultaran profitosos en la nostra tasca d'ensenyament de la llengua i de la literatura. El que aconseguirem principalment amb la geografia literària (i lingüística) serà donar a conèixer les possibilitats lingüístiques i de patrimoni que amaga la ciutat (en particular en aquesta ocasió) i el País Valencià en general, de manera que reforçarem l'actitud positiva de l'alumnat envers la identitat valenciana. A més, hem d'entendre com un fet d'innovació educativa el treball fora de l'aula. La raó n'és ben senzilla: la motivació de l'alumnat i l'autogestió d'una part del seu procés d'aprenentatge. Aquesta darrera qüiestió afegirà, també, la promoció lingüística i literària de manera tant directa com indirecta: d'una banda, l'efecte que tindrà sobre l'alumnat que participa en la ruta; de l'altra, la transmissió que facen aquests o la publicitat que se li done a l'esdeveniment. 


\section{BIBLIOGRAFIA}

Bataller, A. (2011): «Geografies literàries», Futura, 22, 32-35.

- (2014): «Per una didàctica de la llengua i la literatura vinculada al territori» en BATALLER, A. i H.H. Gassó (eds.), Un amor, uns carrers. Cap a una didàctica de les geografies literàries, València, Publicacions de la Universitat de València, 13-21.

Mira, J.F. (1989): Els treballs perduts, València, $3 i 4$.

- (2003): Purgatori, Barcelona, Proa.

- (2007): «Territori, llengua, literatura, identitat» en EsPAIS EsCRITS (2011), Literatura, territori $i$ identitat: la gestió del patrimoni literari a debat, Girona, Curbet, 75-85.

- (2008): El professor d'història, Barcelona, Proa

SAVATER, F. (2013): Las ciudades y los escritores, Barcelona, Debate

SERRANO, D. (2007): «El valor didàctic del treball fora de l'aula. Reflexions des de la Geografia», Observar, $1,106-118$.

VILÀ, M. (coord.) (2002): Didàctica de la llengua oral formal. Continguts d'aprenentatge i seqüències didàctiques, Barcelona, Graó.

\section{BIONOTA}

Anna Laura Díaz Iglesias és Llicenciada en Filologia Catalana, Màster en Assessorament Lingüístic i Cultura Literària: aplicacions al context valencià i màster en Formació del Professorat. Exerceix de docent a la Universitat Jaume I, així com en un centre de secundària. La seua línia de recerca principal és l'obra narrativa de Joan Francesc Mira i possibles explotacions didàctiques d'aquesta, sobre la qual està elaborant una tesi doctoral a la Universitat Jaume I. 